\title{
RELEVANSI DAKWAH SUFISTIK IMAM GHAZALI \\ BAGI MASYARAKAT INDONESIA
}

\author{
Muh. Wasith Achadi ${ }^{1}$
}

\begin{abstract}
In today's contemporary era, one of the many problems experienced by the world community is the spiritual restlessness. Spiritual restlessness is not only felt by the Western people, but also by the people of Indonesia. According to some experts, to address the problems that plague contemporary society, it is very possible using sufistic propaganda to answer the crisis of meaning. Here, sufistic propagada means delivery of sufistic discourses or esoteric dimensions of islamic doctrine to the public. Because contemporary human problems are spiritual emptiness, then it should be treated with something that is spiritual. This paper will discuss the relevance Imam Ghazali's propaganda for Indonesian contemporary society.
\end{abstract}

Keywords: Relevance, Sufistic Propaganda, Imam Ghazali, Indonesian People

\section{Pendahuluan}

Penelitian para ahli mengenai kecerdasan spiritual memastikan kalau orangorang kontemporer di Barat sudah kehilangan makna hidup dan menjadi bodoh secara spiritual. Masyarakat Barat sudah mengalami kegersangan spiritual secara akut. Namun menariknya, kehampaan makna hidup, gelisahan dan kegersangan spiritual ini bukan hanya dialami oleh orang-orang Barat melainkan juga dialami oleh masyarakat Indonesia dewasa ini.

Seorang ilmuwan, Ben Anderson, mengatakan bahwa orang-orang kaya di Indonesia mengalami apa yang disebut Existential Vacuum atau kekosongan eksistensial. Kekosongan eksistensial itu ditandai dengan kebosanan dan ketidakjelasan hidup. Karena tiba-tiba mereka terangkat dari suatu budaya,

\footnotetext{
${ }^{1}$ Dosen Jurusan Tarbiyah UIN Sunan Kalijaga Yogyakarta Email: m.wasith@yahoo.com
} 
kemudian terbentuk kepada suatu budaya baru. Tiba-tiba mereka memasuki suatu dunia yang luas, dengan duit yang banyak namun tidak tahu bagaimana menghidupi kehidupan ini. Dalam kondisi seperti itulah, mereka ingin kembali kepada hal-hal spiritual. $^{2}$

Nurcholish Madjid melukiskan kalau orang-orang kontemporer mengalami alienasi, perasaan keterasingan dari kesejatian dirinya sendiri, sehingga merasakan kehampaan hidup. Menurutnya bangsa Indonesia belum sampai ke tingkat krisis yang dialami oleh negara-negara industri maju. Tetapi tentu tidak ada salahnya mengambil tindakan antisipatif agar hal semacam itu tidak merata di negara Indonesia karena ongkosnya sangat mahal dilihat dari indikator-indikator lahiriah seperti tingginya angka bunuh diri yang dialami negara-negara maju Skandinavia, seperti Denmark, Swedia dan Norwegia. ${ }^{3}$

Jadi harus ada tindakan antisipatif bagi bangsa Indonesia yang sedang berproses menuju masyarakat Pasca Industri agar tidak terperangkap dalam gelisahan Spiritual dalam mencari dan menemukan makna hidup. Dalam konteks ini, tindakan antisipatifnya tentu saja dengan mensosialisasikan nilai-nilai kebajikan agama. Dalam terminologi agama Islam, hal ini terangkum dalam sebuah kata yakni dakwah. Namun sejauh ini masih tersisa persoalan: dakwah yang bagaimana agar kompatibel bagi masyarakat yang sedang sakit dewasa ini? Melihat permasalahan yang menghinggapi masyarakat kontemporer, maka dakwah sufistik sangat dimungkinkan mampu menjawab krisis makna yang dirasakan masyarakat dewasa ini.

Dakwah sufistik yang dimaksud di sini adalah penyampaian wacana-wacana sufistik (dimensi esoteris) yang besifat keruhanian kepada masyarakat luas. Karena problem manusia kontemporer adalah kehampaan ruhaniah, maka harus disembuhkan dengan sesuatu yang bersifat ruhaniah. Bahkan dalam skala global, Sayyed Hossein Nasr, seorang ilmuwan Iran yang ahli dalam bidang Filsafat dan

\footnotetext{
${ }^{2}$ Miftah F.Rakhmat, Catatan Kang Jalal: Visi Media, Poltik dan Pendidikan (Bandung: Rosdakarya, 1997), hlm. 477.

${ }^{3}$ Ahmad Gaus AK, Atas Nama Pengalaman (Jakarta : Paramadina, 2002), hlm. 66.
} 
Tasawuf, yakin bahwa solusi yang mampu membebaskan manusia modern (kontemporer), baik di Barat maupun Timur, dari kehampaan makna hidup dan kebangkrutan spiritual adalah wacana sufistik. ${ }^{4}$ Lebih jauh, Carl Gustav Jung sebagai Psikolog Swiss yang pertama kali membahas krisis makna dalam kehidupan modern, ${ }^{5}$ ternyata banyak menggali konsep-konsepnya dari tokohtokoh besar tasawuf Islam, seperti Imam Ghazali, Ibnu Arabi dan tokoh-tokoh besar dalam bidang tasawuf lainnya. Hal ini diakui sendiri oleh Jung bahwa ia berhutang kepada dunia Timur dan oleh orang-orang Barat juga. ${ }^{6}$

Dengan demikian, tak terkecuali dengan permasalahan Indonesia mengenai krisis makna dan kegelisahan spritual harus disuguhkan jawaban solusif berupa wejangan-wejangan sufistik yang bersifat ruhaniah. Makalah ini akan mendiskusikan relevansi dakwah sufistik Imam Ghazali bagi masyarakat kontemporer Indonesia. Manusia kontemporer mempunyai penglihatan yang tajam, jernih dan clear untuk menyaksikan aneka panorama kehidupan dunia yang kasat mata, namun sebenarnya mereka buta. Bukan buta warna, tapi buta makna. Karena itu mata jiwa mereka harus dibuka dan dicerahkan melalui wacanawacana sufistik Imam Ghazali agar mereka mampu menangkap hakikat makna yang mereka dambakan.

\section{B. Pengrtian Dakwah Sufistik}

Secara sederhana, dakwah dapat diformulasikan kembali sebagai proses penyampaian pesan-pesan keagamaan dari seseorang kepada orang lain baik secara individu maupun secara kolektif, berupa perintah untuk melakukan kebajikan dan mencegah dari kemungkaran melalui lisan, tulisan dan perilaku atau keteladanan agar meraih kebahagiaan di dunia dan di akhirat.

\footnotetext{
${ }^{4}$ Lihat Komaruddin Hidayat, Tragedi Raja Midas, (Jakarta ; Paramadina, 1998), hlm. 265-297.

${ }^{5}$ Jeffrey Lang, Bahkan Malaikat Pun Bertanya, Alih Bahasa Abdullah Ali, (Jakarta: PT Serambi Ilmu Semesta, 2002), hlm. 28; Lihat juga Ladis Laus Naisaban, Psikologi Jung: Tipe Terpribadian Manusia dan Rahasia Sukses dalam Hidup, (Jakarta : Grasindo, 2003), hlm. 8.

${ }^{6}$ Idries Shah, Belajar dari Sufi, Penerjemah Rahmani Astuti (Bandung : Pustaka Hidayah,2002), hlm.15.
} 
Sementara istilah sufistik dalam bahasa Inggris (sufistic) mengandung makna, characteristic of, or practicing sufism ${ }^{7}$, yaitu karakteristik mengenai, atau praktik ajaran tasawuf (sufisme). Tasawuf atau sufisme merupakan aspek mistisisme yang ada dalam agama Islam. ${ }^{8}$ Di lain sisi istilah sufistik menurut Jalaluddin Rakhmat harus diartikan, "Kesufi-sufian" saja, serupa dengan kata tasawuf, yang berarti "sufi-sufian". ${ }^{9}$ Kesufi-sufian atau bersufi-sufian bukanlah berarti tidak ada kesungguhan dalam mengaplikasikan ajaran-ajaran agama, melainkan makna itu menunjukkan proses perjalanan seorang hamba dalam mendekat kepada Tuhannya.

Pengertian sufistik dari Jalaluddin Rakhmat ini setidaknya dapat diidentikkan dengan definisi mutashawwif oleh al-Hujwiri. Al-Hujwiri menyatakan bahwa "Mutashawwif adalah orang yang berusaha keras untuk mendekat kepada Tuhan dengan cara menundukkan hawa nafsunya atau melalui mujahadah. Ini karena menurutnya tashawwuf termasuk ke dalam bentuk tafa'ul, yang mengandung arti bersusah payah. ${ }^{10}$

Dari paparan singkat di atas, maka yang dimaksud dengan dakwah sufistik dapat didefinisikan sebagai sebuah usaha dalam mensosialisasikan ajaran-ajaran Islam oleh seseorang ( $\left.d a^{\prime} i\right)$ kepada orang lain (mad'u) baik secara individu maupun kolektif, melalui lisan, tulisan, ataupun keteladanan untuk mengerjakan kebajikan dan menjauhi kemungkaran. Konsep yang diaplikasikan adalah melalui pendekatan tasawuf, yakni penyampaian pesan moral keagamaan dengan lebih memprioritaskan sisi ruhaniah sasaran (objek) dakwah, ketimbang sisi jasmaniahnya. Pesan-pesan moral keagamaan yang ditransmisikan berupa wacana-wacana atau materi-materi tasawuf seperti tobat, zuhud, sabar dan lainlain, untuk membersihkan dan mensucikan hati dari segala noda-noda maksiat sehingga manusia bisa meraih kebahagiaan di dunia dan di akhirat.

\footnotetext{
${ }^{7}$ Noah Webster, Webster's New Twentieth century Dictionary, (Amerika Serikat: William Collins, 1980), hal. 1821.

${ }^{8}$ Harun Nasution, Falsafat dan mistisme Dalam Islam, (Jakarta; Bulan Bintang, 1995), hal. 56.

${ }^{9}$ Jalaluddin Rakhmat, Renungan-Renungan Sufistik, (Bandung : Mizan, 1994), hlm. 6-7.

${ }^{10}$ Ali Ibn Utsman al-Hujwiri, Kasyful Mahjub, Penerjemah Suwardjo Muthary dan Abdul Hadi WM, (Bandung: Mizan, 1993), hlm. 44
} 


\section{Dakwah Sufistik Imam Ghazali dan Relevansinya}

Di sini konsep penyampaian wacana-wacana sufistik Imam Ghazali melalui tahapan-tahapan maqamat seperti; tobat, sabar, syukur, fakir, zuhud dan mahabbah (cinta). ${ }^{11}$ Materi-materi sufistik yang akan dibahas diambil dari wacana-wacana tasawuf yang oleh para ulama sufi dijadikan maqamat (stasion) atau tahapan yang harus dilalui oleh seseorang agar bisa mencapai pencerahan spiritual dan meraih ketenangan ruhaniah karena telah merasakan kedekatan dengan Allah, As-Salam Tuhan Yang Maha Damai. Karena begitu luasnya spektrum wacana materi sufistik, maka dalam risalah ini kami membatasi pembahasannya pada lima aspek saja yaitu, tobat, zuhud, sabar, syukur, dan cinta. a. Tobat.

Secara etimologi makna tobat dalam bahasa Arab adalah kembali (alruju'). Ungkapan, "ia bertobat" berarti “ia kembali”. 12 Imam Qusyairy mendefenisikan tobat dengan singkat namun komprehensif: yakni kembali dari sesuatu yang dicela oleh syara' menuju sesuatu yang dipuji olehnya. ${ }^{13}$ Dalam perspektif Al-Ghazali, taubat mencakup tiga unsur yang tersusun secara tertib yaitu ilmu, keadaan ( $h a l$ ), dan perbuatan. Dengan ilmunya, seseorang mengetahui sepenuh hatinya tentang besarnya bahaya dosan dan dosa-dosa tersebut menjadi dinding penghalang antara dirinya dan Tuhannya. Ketika ia menyadari hal itu, maka ia merasa terluka hatinya atas perbuatannya yang menjauhkan dari Tuhannya dan ia pun menyesali perbuatannya. Kemudian ia bertekad yang mencakup tiga dimensi waktu: ia tidak akan mengulangi dosadosa yang telah dilakukan di masa silam, meninggalkan segera dosa-dosa yang ia lakukan sekarang, dan mengisi masa depan dengan segala macam kebajikan sebagai pengganti keburukan-keburukan yang telah ia lakukan di masa silam.

Dengan demikian, dalam padangan Ghazali, makna taubat secara ideal harus mencakup kesadaran terhadap bahaya dosa yang menimbulkan penyesalan dan segera diikuti dengan tindakan-tindakan konkret dengan

\footnotetext{
${ }^{11}$ Lihat Abu Hamid Al-Ghazali, Ihya ulum Al-Din, jilid IV, (Libanon: Dar Al-Fikr, 1995)

${ }^{12}$ Ibid.

13 Abul Qasim Al-Qusyairy An-Naisabary, Al-Risalah-Al-Qusyairiyyah, (Dar Al-Khoir,
} tt), hlm. 91 . 
meninggalkan semua perbuatan dosa tersebut serta mengisinya dengan berbagai kebajikan sebagai penggantinya. Bahkan lebih jauh, bagi Ghazali, secara hakiki setiap kita harus bertaubat dalam setiap keadaan. Kalau kita bisa menjaga anggota badan kita dari perbuatan-perbuatan maksiat, maka hati kita tidak sunyi dari bisikan-bisikan maksiat. Jika hati kita bersih dari bisikanbisikan maksiat (ini saja sudah sangat suli atau langka), maka datanglah bisikan setan yang melalaikan kita dari Allah. Apabila kita selamat juga dari bujukan setan (ini merupakan kondisi orang yang dekat dengan Allah, selalu zikir kalbunya), maka kita tetap mempunyai kelalaian dalam memahami kebijaksanaan Allah, sifat-sifat-Nya, dan perbuatan-perbuatan-Nya. ${ }^{14}$

Sampai di sini, lalu apa relevansi tobat bagi masyarakat kontemporer? Imam Ghazali dalam karyanya Minhajul Abidin, menjelaskan secara umum ada dua argumen mengapa seseorang harus melakukan tobat, yakni supaya ia berhasil mengaplikasikan ketaatan dan agar ibadahnya diterima oleh Allah SWT, yang keduanya berpijak pada kejernihan dan kelembutan hati disebabkan bertobat dari kelalaian, kesalahan dan dosa. Sebab perbuatan maksiat tidak sekadar membuat hati menjadi hitam, kotor dan keras sehingga enggan beribadah, melainkan juga akan menjadikan ibadahnya tidak diterima Allah karena ia beribadah kepada Allah dengan sesuatu yang membuat-Nya murka.

Selanjutnya Ghazali mengajukan pertanyaan-pertanyaan yang sifatnya komtemplatif dan metaforik: "Sungguh aneh! Bagaimana akan dapat melaksanakan ketaatan seseorang yang tenggelam dalam keburukan dan keras hatinya? Dan bagaimana akan diterima sedekahmu sedangkan hutangmu belum kau tunaikan? ${ }^{15}$ Penjelasan Ghazali kendati telah berabad-abad lalu masih relevan untuk menjawab problem masyarakat dewasa ini. Problem utama masyarakat kontemporer adalah kegersangan spiritual. Kehidupan mereka hampa dari makna. Orang-orang ini mencari sesuatu yang bersifat transendental. Demi memperoleh hal tersebut di samping terbawa arus kehidupan hedonistik dan materialistik, mereka juga beribadah, mengabdi dan

\footnotetext{
${ }^{14}$ Imam Al-Ghazali, Ihya' Ulumuddin Juz IV (Libanon: Beirut, 1995), hlm. 9.

${ }^{15}$ Lihat Abu hamid Al-Ghazali, Minhaljul Abidin, (Surabaya: Al-Hidayah, tt), hlm. 10 ; Minhajul Abidin, Penerjemah Zakaria Adhom, (Jakarta: Darul Ulum Press, 1996), hlm. 55-56.
} 
menyembah Allah. Mereka mengaplikasikan kewajiban ritual yang terangkum dalam rukun Islam seperti salat, zakat, puasa dan haji. Bahkan banyak pula di antara mereka yang menunaikan ibadah haji berulang kali. Namun kenapa mereka masih merasakan keresahan batiniah di tengah kesenangan hidup dan pengabdiannya ?

Seperti kata Ghazali mereka mencampuradukkan antara yang baik dan yang buruk, antara yang benar dan yang salah. Mereka mencari sesuatu yang berarti dalam kehidupannya dengan menggabungkan antara ketaatan dan kemaksiatan, antara pegabdian dan kedurhakaan. Jiwa mereka dipenuhi dengan gambaran dunia yang materialistik. Uang, rumah yang mewah, kendaraan yang megah, makanan dan minuman yang lezat, reputasi sosial dan kedudukan yang tinggi menjadi tujuan intrinsik mereka.

Dalam kondisi seperti ini, hati mereka menjadi keras (qaswah), karena kalbu yang bersifat spiritual dan selalu merindukan sesuatu yang bersifat transendental, justru dijejali dengan tujuan-tujuan sempit dan palsu yang bersifat material. Dalam perspektif sufistik, sebenarnya mereka telah terperangkap dalam kemaksiatan hawa nafsu atau kepentingan diri sendiri (vested interest) dan sesungguhnya pengabdian mereka hanya kamuflase dan formalitas semata tanpa disertai ketulusan hati.

Sejatinya mereka belum menunaikan ketaatan dan keresahan jiwa yang menggerogoti kehidupannya sebagai tanda kesalehan mereka belum terjawab. Kesemuanya ini bersumber pada hati mereka yang sudah penuh dengan noda, menjadi hitam dan keras, sehingga sulit untuk mencapai ketenangan jiwa. Sebab kedamaian ruhaniah hanya bisa diraih dengan pencerahan spiritual dan kejernihan hati melalui proses tobat.

Ibn Athaillah memperkuat argumentasi Ghazali dengan salah satu aforisme hikmahnya; "Bagaimana hati akan bercahaya sedangkan gambar dunia terlukis dalam cermin hatinya ? Atau bagaimana hati menuju kepada Allah sementara ia masih terbelenggu oleh gejolak hawa nafsunya? ${ }^{16}$ Menuju kepada Allah (Yarhalu 'ilallah) Yang Maha Damai akan membuahkan

\footnotetext{
${ }^{16}$ Ibn Abbad, Syarhul Hikam, (Semarang: Darul Ihya, tt), hlm. 17.
} 
kedamaian. Namun bagaimana bisa meraih ketenangan bila hati masih terbelenggu berbagai kepentingan syahwat? Memasuki hadirat Allah (yadkhula hadhrotallah) yakni memasuki hakikat pengabdian juga akan memberikan kecerahan kalbu. Tapi bagaimana jika ia belum menyucikan hatinya dari nodanoda kemaksiatan?

Makanya wajar, jika dalam wacana-wacana sufistik seluruh ulama tasawuf sepakat bahwa seseorang yang akan bertaqarrub kepada Allah, pertama kali harus membuka pintu tobat agar mengalami kecerahan kalbu, sehingga menemukan kedamaian karena Dia Yang Maha Suci tidak bisa didekati kecuali melalui hati yang bersih dari segala maksiat dan dosa. Jadi penyucian kalbu menjadi wahana yang begitu sentral dan fundamental untuk meraih kedamaian hidup dan menemukan makna yang hakiki.

Oleh kerena itu, tak terkecuali masyarakat kontemporer yang sedang diselimuti kehampaan spiritual seyogyanya melakukan tobat secara kaffah (komprehensif). Mereka mesti membersihkan diri dari segala sifat-sifat hewani yang senang berhura-hura, berfoya-foya dalam budaya konsumtif dan hedonistik semata. Mereka juga selayaknya meyucikan jiwa dari sifat-sifat tercela seperti takabbur, ujub, rakus, dengan kedudukan dan kekuasaan dan sebagainya. Dengan demikian kalbu mereka menjadi suci, bersih dan mengalami pencerahan sehingga mereka menemukan kedamaian dan kebahagiaan hakiki sebagai puncak makna hidup yang mereka idam-idamkan selama ini.

b. Zuhud.

Zuhud secara Literal berarti penarikan diri dari kesenangan duniawi dan menolak keinginan nafsu rendah. Zuhud oleh para sufi diartikan sebagai "ketidak pedulian kepada daya tarik duniawi dan hidup dengan cermat dan dengan memilih untuk menghindarkan diri dari semua dosa, memandang rendah dunia dalam aspek material dan nafsunya". ${ }^{17}$ Imam Ghazali mendefinisikan zuhud sebagai suatu ibarat mengenai berpalingnya kesenangan

\footnotetext{
${ }^{17}$ Fathullah Gulen, op. cit, hlm. 79.
} 
(kesukaan) terhadap sesuatu yang lebih baik dari padanya. ${ }^{18}$ Dengan kata lain, zuhud itu suatu ibarat tentang tidak sukanya seseorang terhadap dunia karena berpaling kepada akhirat atau ia berpaling dari selain Allah menuju kepada Allah. ${ }^{19}$

Selanjutnya Ghazali membagi stratifikasi zuhud bila dihubungkan dengan sesuatu yang disukai, maka terklasifikasi dalam tiga tingkatan. Pertama, merupakan derajat terendah dimana seseorang sangat menginginkan keselamatan dari siksa neraka dan dari semua kesengsaraan-kesengsaraan lain seperti siksa kubur, perkara penghisapan amal, bahaya melintasi shirat dan seluruh huru-hura lainnya yang akan dihadapi seorang hamba di akhirat kelak. Zuhud dalam tataran ini berpijak pada perasaan takut. Karena itu dinamakan zuhudnya orang-orang yang takut terhadap siksaan (zuhdul khaifin).

Kedua, zuhudnya seseorang karena mengharapkan pahala dari Allah, kenikmatan dan kelezatan-kelezatan lain yang dijanjikan dalam surga-Nya, seperti para bidadari, kemegahan istana surga dan semua kesenangan lainnya. Zuhud dalam dimensi tersebut bersandar pada pengharapan pahala dari Allah dan kenikmatan surga yang abadi. Oleh sebab itu disebut sebagai zuhudnya orang-orang yang mengharapkan pahala Allah (zuhdur rajin).

Ketiga, merupakan tingkat tertinggi yaitu apabila seseorang tidak memiliki kesukaan kecuali suka kepada Allah dan senang bertemu dengan Allah. Hatinya tidak memandang kepada kesengsaraan (siksaan neraka) dengan maksud agar selamat dari kesengsaraan tersebut. Ia tidak pula berpaling kepada kelezatan-kelezatan (pahala dan segala kenikmatan surga) dengan tujuan supaya bisa memperolehnya dan mencapainya. Hati seseorang yang zuhud dalam wilayah ini sudah dipenuhi dengan kecintaan kepada Tuhan semata. Itulah alasanya mengapa zuhud dalam tatanan ini dinamakan zuhudnya orangorang yang mencintai Allah SWT. ${ }^{20}$

Secara global, seorang yang menjalani praktek zuhud atau zahid adalah orang yang tabah dalam memenuhi tanggung jawabnya dan menangkal segala

\footnotetext{
${ }^{18}$ Ghazali, op. cit., hlm. 185.

${ }^{19}$ Ibid.

${ }^{20}$ Ibid. hlm. 193.
} 
ancaman yang menimpa dirinya, serta dalam menghindari jebakan dosa dan perangkap setan yang dipasang di jalan yang dilalui. Dia puas dengan semua keputusan yang ditetapkan oleh Penciptanya untuk dirinya dan puas dengan apapun yang dilakukan terhadap dirinya. Dia juga adalah orang yang bertujuan memperoleh ridha Allah dan tempat kebahagiaan abadi melalui berkah dan karunia-Nya yang diturunkan kepada dirinya dan dengan mengajak orang lain untuk menuju kebenaran. $^{21}$

Satu hal yang perlu ditegaskan dalam hal ini yaitu zuhud atau sikap berpaling kepada sesuatu yang lebih dicintai disini adalah kondisi ruhaniah orang yang mengaplikasikannya, bukan berpaling secara jasmaniah, walaupun hal ini juga mungkin terjadi. Walaupun secara jasmaniah ia bergaul bersama dunia dengan segala kenikmatan dan kesenangannya, namun jiwanya terbebaskan dari semua itu. Di awal risalahnya. "Ihya ulum al-din" dalam kitab "Ilmu", ketika menyinggung sekilas tentang zuhud Ghazali dengan tegas mengatakan : "Bukanlah zuhud itu tidak memiliki harta benda, sesungguhnya zuhud itu adalah kosongnya hati dari harta." 22

Keterlepasan hidup manusia dari hal-hal yang berbentuk material seperti makanan dan minuman, harta benda, tempat tinggal, isteri atau suami dan anak-anak merupakan suatu yang sulit, bahkan mustahil betapapun kecilnya hal tersebut. Alasannya, kecintaan kepada semua yang bersifat material ini sudah menjadi fitrah atau bekal primordial yang Allah disain dalam setiap ranah batin manusia dan tak seorangpun bisa menghindar darinya. Al-Qur'an menegaskan fenomena faktual ini :

"Dijadikan indah pada pandangan manusia kecintaan kepada apa-apa yang diingini, yaitu: wanita-wanita, anak-anak, harta yang banyak dari jenis emas dan perak, kuda pilihan, binatang-binatang ternak, dan sawah ladang. Itulah kesena- ngan hidup didunia; dan di sisi Allah-lah tempat kembali yang baik (surga)". (Ali-Imran : 14). ${ }^{23}$

Yang diinginkan Allah dalam ayat tersebut adalah cinta yang proporsional. Seluruh kesenangan dunia yang dipaparkan dalam ayat di atas

${ }^{21}$ Gulen, op. cit., hlm. 80 .

${ }^{22}$ Ghazali, jilid I, op. cit., hlm. 31.

${ }^{23}$ Depag, op. cit., hlm. 77. 
mesti dinikmati dalam sebuah prinsip bahwa semuanya merupakan kesenangan sementara yang diberikan Allah kepada manusia dipentas kehidupan yang fana. Manusia tidak boleh larut dengan semua kesenangan dunia itu dan melupakan kenikmatan akhirat yang jauh lebih mulia. Makanya di akhir ayat ditegaskan bahwa di sisi Allah terdapat surga sebagai tempat yang baik.

Persoalannya dalam konteks ini ialah banyak manusia tergoda kesenangan jangka pendek yang bersifat temporal dan melupakan kenikmatan jangka panjang yang bersifat immortal. Semua kesenangan material duniawi dalam segala bentuknya baik harta benda, tahta atau kekuasaan dan wanita menjadi tujuan utamanya sehingga melalaikan bahkan mengesampingkan kebahagiaan ukhrawi yang kekal. Mereka terjebak dengan menganggap sesuatu yang sifatnya instrumental sebagai sesuatu yang substansial. Kondisi yang menurunkan nilai hakiki kemanusiaan ini kemudian sering diistilahkan sebagai become a captive of here and now yakni menjadi terbelenggu dalam kekinian dan kesekarangan. ${ }^{24}$

Dalam konteks inilah, akan terlihat relevansi zuhud bagi masyarakat kontemporer yang mengalami kegersangan spiritual. Penyebab krusial penyakit ruhaniah masyarakat dewasa ini dikarenakan mereka begitu berambisi memenuhi semua keinginan biologis dan melupakan kebutuhan psikologis. Mereka hanya digerakkan oleh kepentingan hawa nafsu belaka dan tidak pernah menyadari kebutuhan instrinsiknya berupa God-consiousness, kesadaran akan kehadiran Tuhan di dalam dirinya sebagai kerinduan eksistensial dalam mengejar puncak tujuan dan makna dalam kehidupannya.

Sementara kebutuhan biologis atau aspek fisikal manusia tidak akan pernah terpuaskan jika dimensi psikisnya dikesampingkan. Kepentingan luar atau jasmaniah adalah kondisi yang perlu (necessary condition), tetapi itu saja tidak mencukupi, tanpa dibarengi dengan pemenuhan kebutuhan ruhaniahnya. Sebab kebutuhan yang di dalam itulah yang akan mencukupi atau memuaskan (sufficient condition). ${ }^{25}$ Adalah sebuah paradoks yang wajar bila manusia yang

\footnotetext{
${ }^{24}$ Nurcholis Madjid, 30 Sajian Ruhani, (Bandung: Mizan, 1999), hlm. 92.

${ }^{25}$ Kuntowijoyo, Identitas Politik Umat Islam, (Bandung: Mizan, 1997), hlm. 11.
} 
sudah memiliki segala idaman materialnya seperti uang, rumah yang megah, pangkat yang tinggi, isteri yang cantik, dan kendaraan yang mewah, namun masih merasakan kesengsaraan berupa kehampaan batiniah.

Di sisi lain, menurut Moeslim Abdurrahman bagi sejumlah besar masyarakat Indonesia yang sudah terjebak dalam budaya konsumerisme kontemporer, harus ada kekuatan moralitas yang resisten seperti moralitas zuhud. Agama harus tampil sebagai ideologi sosial yang mengartikulasikan wacana-wacana moralitas keagamaan yang mampu meng-counter the consumer society, masyarakat konsumtif yang berwatak hedonistik tesebut. Sehingga secara moral agama, orang merasa bersalah kalau ia melakukan konsumsi dengan rakus, sementara di sekitarnya orang hidup dalam keterbatasan yang luar biasa dan juga supaya subyek-subyek manusia kreatif tetap terjaga sebagai kekuatan penyelamat yang mampu melakukan tawarmenawar tentang apakah sesungguhnya makna manusia dalam kehidupan ini.

Karena dalam budaya konsumerisme, sebenarnya jati diri seseorang yang asli (an authentic-self) tidak ada. Karakter dan gambaran subjek merupakan sesuatu yang dikonstruksikan secara sosial. Subyek-subyek masyarakat adalah kumpulan konsumen yang menjadi pembeli terhadap cerita, ide, dan ilusi yang ditawarkan periklanan. ${ }^{26}$ Dengan nada keprihatinan Moeslim Abdurrahman menawarkan sebuah solusi alternatif dan dengan tegas pula ia mengatakan bahwa, "Tanpa Islam yang berwajah asketis (zuhud) ini muncul sebagai alternatif, saya kira, fungsi agama yang sesungguhnya harus menyuarakan solidaritas kemanusiaan akan menjadi redup. Atau pesan agama menjadi ambigu secara moral, tatkala harus berhadapan dengan rakusnya manusia dalam era konsumsi dunia sekarang ini., ${ }^{27}$

Pada titik ini semakin jelas kiranya relevansi zuhud bagi masyarakat era kini yang terperangkap dalam budaya konsumtif. Obsesi mereka dalam pleasure seeking, hanya mengejar kesenangan lahiriah dan berpoya-poya semata, harus diubah dengan pencarian puncak makna yang melampaui tujuan

6.

${ }^{26}$ Moeslim Abdurrahman, Islam Sebagai Kritik Sosial, (Jakarta: Erlangga, 2003), hlm. 5${ }^{27}$ Ibid., hlm. 7. 
duniawi (terestrial) dan menembus tujuan hidup ukhrowi (celestial). Orientasi mereka yang sudah terjerat dalam kerangkeng kekinian dan kedisinian (now and here oriented) harus dibebaskan melalui orientasi masa depan, orientasi ukhrowi (future oriented).

c. Sabar.

Kata shabr (sabar) tersusun dari dari huruf shad, ba dan ra. Ia adalah bentuk mashdar (bentuk nomina) dari fiil madhi (kata kerja bentuk lampau) shobaro. Arti asal kata tersebut adalah "menahan", seperti mengurung binatang, menahan diri dan mengendalikan jiwa. Kata ini dipergunakan untuk objek yang sifatnya material maupun immaterial. ${ }^{28}$ Secara umum sabar didefinisikan dengan ketabahan dalam menghadapi sesuatu yang sulit, berat dan pahit, yang harus diterima dan dihadapi dengan penuh tanggung jawab. Para agamawan merumuskan pengertian sabar sebagai menahan diri atau membatasi jiwa dari keinginannya demi mencapai sesuatu yang baik atau lebih baik (luhur). ${ }^{29}$

Menurut Ghazali kehidupan manusia tidak pernah terlepas dari dua hal yaitu sesuatu yang sesuai dengan hawa nafsu dan sesuatu yang tidak cocok dengan hawa nafsunya bahkan ia tidak menyukainya. Dalam kedua hal di atas manusia dituntut untuk menghadapi dengan sabar. Sesuatu yang tidak sesuai dengan hawa nafsu adalah segala bentuk ujian dari Allah seperti penyakit, kemiskinan hidup, kematian dan penderitaan lainnya. Kesabaran dalam hal ini sudah dimaklumi dan telah dibahas sebelumnya.

Yang menarik, dalam perspektif Ghazali manusia juga harus bersabar terhadap segala hal yang disenangi hawa nafsunya, seperti kesehatan, harta, kedudukan, banyak keluarga, luasnya sebab-sebab, banyaknya pengikut dan penolongan serta semua kelezatan dunia. Sabar di sini adalah ketabahan dalam menggunakan semua kenikmatan tersebut dalam koridor hukum-hukum agama, tidak berlebihan sehingga tergelincir dalam perbuatan maksiat dan menunaikannya sesuai dengan haknya masing-masing secara proporsional.

\footnotetext{
${ }^{28}$ Hamdar Arriyyah, Sabar Kunci Surga, (Jakarta,: Khazanah Baru, 2002), hlm. 117.

${ }^{29}$ Quraish Shihab, Secercah Cahaya Ilahi, (Bandung, Mizan, 2001), hlm. 119.
} 
Apabila seseorang diberi kesehatan yang sempurna dan kekayaan yang cukup atau berlebihan, maka kesabaran yang dituntut adalah ia tidak membiarkan hawa nafsunya bersenang-senang secara berlebihan dengan semua kenikmatan itu hingga terjebak dalam kedurhakaan kepada yang menitipkan semuanya. Lebih jauh seseorang yang mendapatkan segala kenikmatan yang sesuai dengan kesukaannya, dituntut untuk menjaga hak-hak Allah. Dengan hartanya ia harus berinfak ;pada tubuhnya yang sehat ia memberikan bantuan ; dengan lisannya ia menyampaikan kebenaran dan begitu pula pada semua yang dikarunikan Allah kepadanya. Pada aspek ini sabar berhubungan dengan syukur bahkan sabar tidak sempurna kecuali dengan melaksanakan hak syukur. $^{30}$

Kendati syukur dalam hal ini berperan, tetapi dalam konteks pembahasan ini yang lebih dominan perannya adalah kesabaran. Dan ketika kondisi kenikmatan dan kesenangan dunia hadir dengan sempurna dalam kehidupan manusia, maka bersabar atasnya menjadi sangat berat melebihi saat-saat dalam penderitaan dan kesusahan. Sampai di sini semakin jelas, tak seorang pun yang dapat terlepas sama sekali dari sabar. Karena setiap orang pasti menghadapi salah satu dari dua kondisi yakni bersama sesuatu yang disukai atau bercengkerama dengan sesuatu yang tidak ia senangi. Dalam kedua kondisi itu kesabaran mutlak dibutuhkan sehingga sabar harus dijadikan kendaraan hidup dalam setiap tarikan nafasnya. Sebab, sebagaimana tubuh tidak bisa dikatakan hidup tanpa adanya kepala, begitu pula keimanan seseorang tidak akan bermakna tanpa hadirnya kesabaran.

Pada titik inilah akan telihat lebih konkret relevansi kesabaran bagi masyarakat kontemporer. Setidaknya ada dua aksentuasi hubungan sabar terhadap masyarakat dewasa ini yang sudah begitu larut budaya materialistik. Pertama, kesabaran penting bagi kaum elit yang masih juga berpacu dalam persaingan tanpa arah dalam mengejar kekayaan, kemewahan dunia dan segala jenis reputasi sosial yang tinggi. Kesabaran di sini harus menjadi kendali dalam mengekang keinginan mereka yang tak akan ada titik finisnya. Meskipun

\footnotetext{
${ }^{30}$ Ibid., hlm. 344-347.
} 
sebagian ilmuwan menisbahkan ambisi mereka karena tergoda atau mengikuti arus cerminan sosial yang sudah memasyarakat bahkan mendunia akibat pengaruh dunia Barat dan Eropa, sebenarnya faktor terkuat yang membawa mereka terjebak dalam budaya konsumerisme adalah gejolak hawa nafsu dalam diri sendiri yang selalu mereka ikuti.

Berbagai godaan, bujukan atau pengaruh eksternal untuk mengejar kehidupan yang berlebih-lebihan dalam kemewahan dunia dan ambisi kedudukan atau kesuksesan, tetap tidak akan mempunyai efek atau dampak negatif bagi orang-orang yang telah terbekali dengan kesabaran dalam menaklukkan keinginan materialistik internalnya.

Kedua, Bagi orang-orang yang begitu larut dalam pleasure seeking, menjejali dirinya dengan kesenangan dan kenikmatan jasmaniah semata karena semua kebutuhannya tersedia, maka kesabaran pun menjadi signifikan sebagai pengekang nafsu hedonistik mereka. Menurut Moeslim Abdurrahman memang hasrat hedonistik mereka disebabkan terobsesi periklanan dunia yang telah merajalela dan menyelubungi setiap aspek kehidupan manusia kontemporer. Namun lagi-lagi, penyebab yang paling esensial adalah nafsu konsumtif mereka dalam mengecap kesenangan jasadiah semata dan dikarenakan pula fasilitas keperluannya serba mendukung. Sabar pada dimensi ini, seperti penjelasan Ghazali di atas, menjadi sangat berat. Alasannya, ia merupakan bentuk kesabaran terhadap hal-hal yang sangat disukai oleh hawa nafsu dan terlebih lagi telah menjadi kebiasaan bagi orang-orang kaya era sekarang. Tetapi di situlah letak relevansi kesabaran atas mereka.

Dengan demikian, kesabaran bukanlah berarti kelemahan atau menerima apa adanya, tetapi ia merupakan suatu kekuatan internal dalam diri manusia untuk mengendalikan keburukan ajakan hawa nafsunya. Bahkan sebagian ulama dan ilmuwan seperti Quraish Shihab, Wahbat al-Zuhaili, Toshishiko Izutsu dan al-Razi sepakat bila "sabar merupakan kekuatan yang bersumber di dalam jiwa manusia (quwwat fi al nafs)", ${ }^{31}$ Dalam konteks ini, sabar bukan

${ }^{31}$ Lihat Arraiyyah, Sabar Kunci Surga, hal. 191 dan Quraish Shihab, Secercah Cahaya Ilahi, hlm. 120. 
sekadar menjadi relevan sebagai pengendali masyarakat dewasa ini yang terjerumus dalam lembah kerakusan materialistik, melaikan juga sebagai kekuatan internal untuk mengekang sagala keinginan rendah hawa nafsu dalam memperturutkan hasrat hedonistik yang tiada kesudahan di tengah-tengah kesenangan, kenikmatan, dan kemewahan dunia yang serba ada.

d. Syukur.

Ada beberapa definisi variatif makna syukur dari para ulama. Ada yang mendefinisikan syukur sebagai menggunakannya si hamba kepada semua nikmat yang dianugerahkan Allah kepadanya untuk berbuat sesuatu yang justru untuk itulah ni'mat itu dijadikan/dianugerahkan oleh Allah. ${ }^{32}$ Imam Ghazali memberi pengertian syukur dengan menggunakan nikmat untuk menyempurnakan hikmah nikmat tersebut seperti yang dikehendaki oleh Allah yakni taat kepada Allah. ${ }^{33}$

Berbagai formulasi pengertian syukur yang dipaparkan di atas esensinya tidak berbeda. Syukur merupakan ekspresi rasa terima kasih seorang hamba kepada Tuhannya baik melalui hati, lisan maupun melalui seluruh anggota tubuhnya atas segala nikmat yang telah Dia anugerahkan dengan menggunakan semua nikmat tersebut sesuai dengan tujuan nikmat itu diciptakan dan seperti yang diinginkan oleh Allah SWT. Karena pembicaraan syukur tidak bisa terlepas dari nikmat, maka penting pula dibahas pengertian nikmat dan macammacamnya. Sebagian ulama mendefinisikan nikmat sebagai segala sesuatu yang berlebih dari modal yang dimiliki manusia. ${ }^{34}$

Selanjutnya secara global nikmat terbagi dalam dua katagori yaitu nikmat lahiriah dan nikmat batiniah atau disebut hakikat nikmat. ${ }^{35}$ Nikmat lahiriah adalah segala bentuk kesenangan dunia, seperti kesehatan, kekayaan, kemashuran, pangkat yang tinggi, dan lainya. Sedangkan nikmat batiniah ialah taufik dan hidayat Allah berupa kepatuhan, ketaatan, dan pengabdian kepada-

${ }^{32}$ Imam Akhdlori, Jauhar Maknun, Penerjemah Moch Anwar, (Bandung: Alma'arif, 1993), hlm. 5 .

${ }^{33}$ Lihat Ghazali, Ihya ulumuddin, op.cit., hal. 105 ; Roudhatut Tholibin, (Libanon: Dar Al-Fikr, tt), hlm. 165.

${ }^{34}$ Shihab, op.cit., hlm. 227.

${ }^{35}$ Ghazali, ihya, jilid VII, op.cit, hlm. 457 ; Waly, op.cit., hlm. 449. 
Nya. Jika semua karunia lahiriah di atas tidak dibarengi nikmat batiniah, petunjuk dari Allah, maka semua itu berubah menjadi bencana atau malapetaka. Berbeda dengan nikmat batiniah kendati tidak disertai dengan nikmat lahiriah, akan mengantarkan seseorang meraih kebahagiaan hakiki di akhirat kelak. Dengan alasan ini Ghazali mendefinisikan hakikat nikmat sebagai "kebahagiaan akhirat yang harus diperoleh melalui ketaatan dan pengabdian kepada Allah (Anni'mah bilhaqiqoh hiya assa'adatul ukhrowiyah)."36

Jadi segala kenikmatan lahiriah dari yang terkecil sampai yang terbesar mesti dibarengi dengan ketaatan berupa rasa syukur kepada Tuhan yang memberi rezeki agar semua kesenangan itu tidak menjadi bencana. Dengan ungkapan lain, tidak saja semua rezeki, seperti kekayaan, kemewahan dunia, kedudukan, makanan yang lezat, betapun kecilnya jika disyukuri akan membuahkan pahala surgawi yang agung, melainkan juga seluruh elemen tubuh manusia baik jasmaniah maupun rohaniah saat dijadikan sebagai instrumen bersyukur, maka ia akan menjadi mulia dalam pandangan Allah.

Lalu di mana relevansi syukur untuk masyarakat kontemporer? Pertama, penghargaan nilai spiritual nikmat mesti lebih diutamakan daripada nilai materialnya. Atmosfer kehidupan orang-orang kontemporer sebenarnya sudah dipenuhi dengan kenikmatan. Kekayaan mereka melimpah ruah; mereka memiliki rumah yang mewah dan mobil yang megah; fasilitas kehidupan mereka serba tercukupi; dalam kehidupan sosial pun status mereka cukup mapan dan tinggi.

Problem utamanya, mereka terlalu terobsesi dengan semua kenikmatan material tersebut dan melupakan nilai spiritualnya berupa taufik dan hidayah Allah yang teraplikasi dalam bentuk ketaatan. Padahal semua bentuk kenikmatan material tanpa dibarengi kenikmatan spiritual yakni pengabdian kepada Allah hanya akan membawa prahara kehidupan baik berupa kehampaan hidup dan kegersangan ruhaniah di dunia, lebih-lebih siksaan di akhirat kelak.

\footnotetext{
${ }^{36}$ Ghazali, ihya, juz IV, op.cit., hlm. 85.
} 
Orientasi materialistik mereka harus diganti dengan orientasi spiritualistik agar kehidupan mereka bermakna. Rasa syukur mereka meski dibangkitkan untuk menyadari bahwa something spiritual (sesuatu yang bersifat spiritual) lebih berharga ketimbang something material (sesuatu yang bersifat material). Kearifan prinsip inilah yang telah digemakan oleh pujangga besar Amerika Ralph Waldo Emerson dua abad yang lalu dan sudah dilupakan oleh kebanyakan generasinya saat ini; great men are they who see that spiritual is stronger than any material force, that thoughts rule the world. "Orang bijak adalah mereka yang mengetahui bahwa agama (nilai spiritual) lebih kuat daripada kekuatan material apapun, pemikiran seperti inilah yang mengatur dunia." 129

Kedua, sebagai konsekuensi yang pertama yakni agar tidak terperangkap dalam kesenangan material semata, penglihatan ruhaniah mereka harus disentuh supaya mampu mengenal Al-Mun'im, Tuhan yang mangaruniai nikmat. Kesadaran ketuhanan dalam diri mereka mesti diaktualisasikan. Tingkatan awam mereka dalam kebutaan menerima nikmat dinaikkan kelevel khawas yang dapat merasakan kasih sayang Tuhan yang telah mengirimkan nikmat tersebut kepadanya. Sehingga mereka bisa menyadari bahwa perhatian dan kasih sayang Tuhan itu lebih berharga ketimbang kenikmatan itu sendiri. Kepada mereka inilah ungkapan bijak ditujukan, "Jadilah kamu hamba dari yang memberikan nikmat, jangan menghamba kepada nikmat yang diberikan". ${ }^{130}$

Ketiga, orang-orang kaya ini harus mensyukuri nikmat yang mereka miliki dengan membagikannya kepada orang-orang yang membutuhkannya, terutama kaum dhu'afa dan orang-orang fakir-miskin. Seorang yang hanya memenuhi keinginan hedonistiknya secara individual dan melupakan orang lain, tidak akan pernah menemukan kenikmatan yang sesungguhnya. Orang yang tenggelam dalam kerakusan konsumtif secara pribadi, ia hanya merasakan Pleasure, kesenangan jasmaniah, bukan Happiness, kebahagiaan.

${ }^{129}$ Stephen W. K. Tan, Golden Quotes Maxims of Wisdom, Penerjemah Sindhi Diah Savira, (Jakarata: Elex Media Komputindo, 1997), hlm. 94.

${ }^{130}$ Hamka, Pandangan Hidup Muslim, (Jakarta: Bulan Bintang, 1992), hlm. 238. 
Padahal makna hidup seseorang ditemukan saat ia merasakan kebahagiaan. Dan hal itu diperoleh dengan mendistribusikan kesenangan yang dimilikinya kepada orang-orang yang memerlukannya. Makna ditemukan dengan "memberi" bukan semata "konsumsi". Kebenaran prinsip ini diakui keabsahannya dalam analisis ilmu psikologi kontemporer. Erich Fromm, psikolog aliran humanistik, mengemukakan pandangan ini dengan indah:

"Memberi adalah pengalaman akan potensi dan vitalitas manusia yang menghasilkan kegembiraan luar biasa. Dalam tindakan memberi, manusia-manusia berkarakter produktif mengalami dirinya sebagai mahluk yang berkelimpahan, yang penuh berkah serta hidup, dan oleh karenanya mereka bergembira. Memberi bagi manusia berkarakter produktif lebih menggembirakan ketimbang menerima. Bukan karena hal tersebut merupakan sebentuk kerugian, karena dalam tindakan memberi terdapat ungkapan akan kehidupan (aliveness),",131

Bahkan menurut Fromm, makna kehidupan seseorang ditemukan tidak saja saat ia memberikan hal-hal yang berbentuk material, tetapi juga ketika membagikan apa saja yang bersentuhan dengan dirinya, sesuatu yang ada dalam dirinya dan dialami dalam kehidupannya yang berbentuk abstrak yang dapat memperkaya arti kehidupan seseorang. Jadi kaum kaya di era ini yang merasakan kehampaan eksistensial, harus mensyukuri kemewahan hidupnya secara faktual dengan cara mendistribusikan sebagian darinya kepada orangorang yang membutuhkan. Karena tidak ada hidup yang lebih bermakna ketimbang kehidupan seseorang yang mampu memberikan sesuatu yang berarti kepada orang lain. Dan semakin intens ia membagikan sesuatu yang berarti kepada orang lain dalam komunitas sosial, semakin besar ia menemukan makna dalam kehidupan individualnya.

e. Mahabbah (cinta)

Istilah "mahabbah" atau lazimnya diartikan dengan "cinta" merupakan sebuah kata yang sangat mudah dan sering diucapkan., namun begitu sulit memberikan batasan definisi yang tepat mengenai makna yang terkandung dalam istilah tersebut. Alasannya, karena cinta melibatkan perasaan terdalam

${ }^{131}$ Erich Fromm, The Art of loving, penerjemah Syafi Alielha, (Jakarta : Fress Book, 2003), hlm. 39. 
seseorang secara totalitas terhadap sesuatu yang dicintainya. Terlebih lagi apabila yang dicintai itu adalah $A l$-Wadud, Tuhan Yang Maha Mencintai dan Maha Dicintai yang memiliki keindahan Paripurna.

Dalam literatur tasawuf ketika kaum sufi berbicara tentang mahabbah, maka yang dimaksud dengannya tidak lain adalah cinta seorang hamba kepada Allah. Karena itulah Imam Qusyairy sebelum menjelaskan makna cinta yang terangkum dalam berbagai istilah, terlebih dahulu mengarisbawahi secara eksplisit bahwa, "Cinta tidak bisa disifati dengan suatu deskripsi, tidak bisa dibatasi dan dijelaskan kecuali dengan cinta itu sendiri." 134 Imam Ghazali mendefinisikan cinta dengan berpijak pada kata "hubb" yakni suatu ibarat mengenai kecenderungan watak (tabiat) kepada suatu yang melezatkan atau menyenangkan. ${ }^{140}$

Cinta juga oleh kebanyakan kaum sufi diformulasikan sebagai hubungan hati dengan Kekasih Sejati atau keinginan tak tertahankan akan diri-Nya, atau berusaha menuruti keinginan dan perintah-Nya sampai masa penyatuan. Semua definisi itu dapat diringkaskan sebagai "berdiri” di kehadiran Ilahi dan bebas dari segala hubungan dan kekhawatiran yang fana. ${ }^{141}$ Dengan uraian singkat di atas semakin transparan bahwa pembicaraan cinta di kalangan kaum sufi adalah ditujukan kepada Allah semata. Allah bukan saja sebagai As-Shamad, Tempat bersandar bagi mereka, melainkan juga sebagai Al-Wadud, Muara segala damba dan cinta setiap pencinta.

Tetapi klaim bahwa Allah merupakan puncak tujuan cinta seorang hamba, bukan hanya monopoli kaum sufi saja. Menurut mereka setiap manusia harus memprioritaskan Allah dalam kecintaannya, karena hanya Allah semata yang paling berhak menerima cinta setiap hamba-Nya. Al-Quran dengan tegas menyampaikan pesan tersebut:

${ }^{134}$ Qusyairy, op. cit.,hlm.401.

${ }^{140}$ Ghazali, Juz IV, op. cit., hlm. 252; Kimia Kebahagiaan, penerjemah Haidar Bagir, (Bandung : Mizan, 1995), hlm. 106.

${ }^{141}$ Gulen, op. cit., hlm. 231. 
"Katakanlah, jika bapak-bapakmu, anak-anakmu, saudara-saudaramu, isteri-isterimu, kaum keluargamu, harta kekayaan yang kamu usahakan, perniagaan yang kamu khawatirkan kerugiannya dan rumah yang kamu sukai, lebih kamu cintai dari pada Allah dan Rasul-Nya dan berjihad dijalanNya, maka tunggulah sampai Allah mendatangkan keputusannya" (AtTaubah : 24). ${ }^{142}$

Dalam ayat ini Allah menyebutkan semua hal-hal pokok yang begitu dekat dan dicintai oleh manusia. Kedua orang tua, anak-anak, keluarga, isteri, harta kekayaan, perniagaan dan tempat tinggal yang indah merupakan sesuatu yang dicintai oleh manusia. Namun kecintaan kepada semua itu tidak boleh melebihi kecintaan terhadap Allah. Dalam konteks ini Allah adalah mustahiq lilmahabbah, Tuhan yang paling berhak menerima kecintaan siapapun melebihi segala sesuatu.

Selanjutnya bagaimana relevansi pembicaraan mahabbah sejauh ini bagi masyarakat Kontemporer? Pertama, kecintaan buta mereka kepada hal-hal yang bersifat material semata, harus dialihkan menjadi kecintaan terhadap Allah. Tak seorangpun dan tidak terkecuali dengan orang-orang era kini yang terlepas dari kecenderungan untuk mencintai keindahan dan kesempurnaan mutlak. Ketika tendensi ini ditujukan kepada objek cinta yang bersifat material semata seperti uang, kemewahan dunia, jabatan dan makanan-makanan yang lezat, ia tidak akan pernah terpuaskan.

Boleh jadi seseorang memburu kekayaan yang menjadi fokus utama kecintaannya. Tetapi setelah meraihnya, maka ia akan mencari kekayaan yang lebih banyak lagi. Mungkin saja seseorang akan terobsesi dengan segala kemewahan dunia seperti kedudukan yang tinggi, tempat tinggal yang megah dan makanan serta minuman yang lezat, namun setelah semua itu dimilikinya ia pasti akan beralih kepada sesuatu yang lebih ideal lagi. Dalam semua kasus ini, intinya mereka tidak terpuaskan karena yang mereka cari tidak berada di sana dan konsekuensi logis dari ketidakpuasan adalah kehampaan hidup atau kegersangan ruhaniah.

Sebagian ulama sufi mengatakan, "Jika kita mengandalkan kemampuan fisik dan fitrah kita menjadikan kehidupan duniawi sebagai tujuan kita dan berfokus pada kesenangan-kesenangannya, maka kita akan tercekik di dalam

\footnotetext{
${ }^{142}$ Depag, op. cit, hlm. 281.
} 
lingkaran yang sangat sempit."158 Karena menurut mereka, "kecakapan dan potensi yang melimpah semacam ini tidak diberikan kepada kita untuk suatu kehidupan duniawi yang temporer, yang tidak signifikan."159

Jadi kecintaan kepada Allah-lah yang bisa memuaskan dahaga jiwa setiap manusia, sebab hal itu merupakan kebutuhan intrinsik mereka yang bersemayam di dalam kalbunya. Dengan alasan ini, maka masyarakat dewasa ini mesti mengubah orientasi objek cintanya terhadap hal-hal material yang penuh kepalsuan dan kekurangan menuju objek cinta hakiki yakni Allah sebagai sumber ketenangan, kepuasan dan keabadian.

Kedua, karena manusia di samping memiliki tendensi intrinsik untuk mencintai Allah, ia juga mempunyai kecenderungan ekstrinsik dalam menyukai hal-hal yang temporal, maka kesukaan mereka terhadap segala hal yang berbentuk material harus dikaitkan dengan kecintaan kepada Allah. Kecenderungan ekstrinsik mereka harus berpijak pada tendensi intrinstiknya. Dengan kata lain, kecintaan mereka terhadap segala hal di dunia yang fana mesti atas dasar cinta kepada Tuhannya.

Sampai sejauh ini, kajian materi dakwah sufistik di atas, subtansinya merupakan ajakan untuk menciptakan spiritualisasi dalam setiap dimensi kehidupan manusia yang telah lama hilang di tengah kehidupan masyarakat kontemporer yang materialistik dan hedonistik sehingga menjadi bodoh secara spiritual. Tobat intinya penyucian dari segala maksiat; zuhud adalah mengosongkan hati dari keruhnya dunia dan sabar serta syukur merupakan dua sayap bagi manusia dalam mengarungi kehidupannya menuju Tuhan karena setiap aspek kehidupan tidak pernah sunyi dari ujian dan kenikmatan; sementara mahabbah menjadi landasan setiap tindakan manusia supaya semua perbuatan mereka betapapun kecil dan sederhananya, menjadi bermakna.

Jauh-jauh hari, di atas pertengahan abad-20 yang lalu, Muhammad Iqbal menggemakan pesan ini dalam karyanya yang monumental, "The Reconstruction of Religion Thought in Islam"; Humanity needs three things today a spiritual interpretation of universe, spiritual emancipation of the individual, and principles of a universal import directing the evoluation of human society on a spiritual basis. ${ }^{160}$ (Kemanusiaan saat ini membutuhkan tiga hal yaitu suatu penafsiran spiritual atas alam semesta, emansipasi spiritual atas

${ }^{158}$ Said Nursi, Al Ahad, Menikmati Ekstase Spiritual Cinta Ilahi, Penerjemah Sugeng Hariyanto dan Fathor Rasyid, (Jakarta: Siraja, 2003), hlm.129.

${ }^{159}$ Ibid.,hlm.132.

160 Sir M.Iqbal, The Reconstruction of Religion Thought in Islam (Lahore: Art Press Suiwalan, 1981), hlm. 179. 
individu dan prinsip-prinsip dasar tentang sebuah tujuan universal yang mengarahkan evolusi masyarakat manusia dengan berpijak pada sebuah ranah spiritual). Kiranya seruan pujangga sekaligus filosof besar dari Pakistan tersebut masih cukup relevan untuk menjawab problematika masyarakat kontemporer.

\section{Kesimpulan}

Dakwah sufistik adalah sebuah usaha dalam mensosialisasikan ajaranajaran Islam dengan lebih memprioritaskan sisi ruhaniah objek dakwah ketimbang sisi jasmaniahnya, melalui pendekatan tasawuf dan materi-materi tasawuf dalam hal ini meliputi lima hal yaitu, Tobat, Zuhud, Sabar, Syukur dan Mahabbah (cinta). Masyarakat kontemporer, khususnya kaum elit, mempunyai karakteristik sebagai masyarakat yang materialis. Orientasi mereka umumnya pada kekuasan semata, pemburuan kekayaan yang tiada akhirnya dan komsumsi makanan dan minuman-minuman lezat serta barang-barang mewah yang tidak ada batasnya merupakan ciri khas yang paling menonjol di era kini. Semua diukur dengan parameter materialistik, sehingga mereka mengalami kehampaan hidup dan kegersangan spiritual sebagai kosenkuensi dan problematika yang harus mereka terima.

Relevansi dakwah sufistik terhadap masyarakat kontemporer dalam hal ini adalah mengalihkan orientasi materialistik mereka menuju orientasi spiritualistik; menyadarkan mereka bahwa kesenangan material dalam bentuk apapun takkan pernah memberi kepuasan dan kedamaian hidup yang hakiki tanpa diimbangi dengan hal-hal yang bersifat spiritual yang merupakan kebutuhan mereka yang paling intrinsik. Dengan demikian mereka akan menemukan makna hidup dan kebahagiaan sejati yang mereka rindukan selama ini. 


\section{DAFTAR PUSTAKA}

Abbad, Ibn Syarhul Hikam. Semarang: Darul Ihya, tt.

Abdurrahman, Moeslim. Islam Sebagai Kritik Sosial. Jakarta: Erlangga, 2003.

Akhdlori, Imam. Jauhar Maknun. Terj. Moch Anwar. Bandung: Alma'arif, 1993.

Al-Ghazali, Abu Hamid. Ihya ulum Al-Din, jilid IV. Libanon: Dar Al-Fikr, 1995. Minhajul Abidin. Terj. Zakaria Adhom,. Jakarta: Darul Ulum Press, 1996.

Minhajul Abidin. Surabaya: Al-Hidayah, tt. Kimia Kebahagiaan. Terj. Haidar Bagir. Bandung : Mizan, 1995. Roudhatut Tholibin. Libanon: Dar Al-Fikr, tt.

al-Hujwiri, Ali Ibn Utsman. Kasyful Mahjub. Terj. Suwardjo Muthary dan Abdul Hadi WM,. Bandung: Mizan, 1993.

An-Naisabary, Abul Qasim Al-Qusyairy. Al-Risalah-Al-Qusyairiyyah. Dar AlKhoir, tt.

Arriyyah, Hamdar. Sabar Kunci Surga. Jakarta,: Khazanah Baru, 2002.

Fromm, Erich. The Art of loving. Terj. Syafi Alielha. Jakarta : Fress Book, 2003.

Gaus AK, Ahmad. Atas Nama Pengalaman . Jakarta : Paramadina, 2002.

Hamka. Pandangan Hidup Muslim. Jakarta: Bulan Bintang, 1992.

Hidayat, Komaruddin. Tragedi Raja Midas. Jakarta ; Paramadina, 1998.

Iqbal, Sir M. The Reconstruction of Religion Thought in Islam. Lahore: Art Press Suiwalan, 1981.

Kuntowijoyo. Identitas Politik Umat Islam. Bandung: Mizan, 1997.

Lang, Jeffrey. Bahkan Malaikat Pun Bertanya. Terj. Abdullah Ali. Jakarta : PT Serambi Ilmu Semesta, 2002.

Madjid, Nurcholis. 30 Sajian Ruhani. Bandung: Mizan, 1999.

Naisaban, Ladis Laus. Psikologi Jung: Tipe Terpribadian Manusia dan Rahasia Sukses dalam Hidup. Jakarta : Grasindo, 2003.

Nasution, Harun. Falsafat dan mistisme Dalam Islam. Jakarta; Bulan Bintang, 1995. 
Nursi, Said. Al Ahad, Menikmati Ekstase Spiritual Cinta Ilahi. Terj. Sugeng Hariyanto dan Fathor Rasyid. Jakarta: Siraja, 2003.

Rahmat, Jalaluddin. Renungan-Renungan Sufistik. Bandung : Mizan, 1994.

Rakhmat, Miftah F. Catatan Kang Jalal: Visi Media, Poltik dan Pendidikan. Bandung: Rosdakarya, 1997.

Shah, Idries. Belajar dari Sufi. Terj. Rahmani Astuti. Bandung : Pustaka Hidayah,2002.

Shihab, Quraish. Secercah Cahaya Ilahi. Bandung, Mizan, 2001.

Tan, Stephen W. K. Golden Quotes Maxims of Wisdom. Terj. Sindhi Diah Savira,. Jakarata: Elex Media Komputindo, 1997.

Webster, Noah. Webster's New Twentieth century Dictionary. Amerika Serikat: William Collins, 1980. 